\title{
Operative Therapy for Heterotopic Scar Pregnancy and Successful Birth of the Intrauterine Foetus - Case Report and Review of the Literature
}

\section{Operative Therapie einer heterotopen Narbengravidität mit erfolgreicher Geburt des intrauterinen Fetus - Kasuistik und Literaturübersicht}

Authors

Affiliations
R. Armbrust ${ }^{1}$, R. Krätschell ${ }^{2}$, W. Henrich ${ }^{1}$, M. David ${ }^{2}$

${ }^{1}$ Dept. of Gynecology, Charité Berlin - Campus Virchow Klinikum, Berlin

${ }^{2}$ Obstetrics, Charité Berlin - Campus Virchow Klinikum, Berlin

\section{Key words \\ - assisted reproduction \\ - extrauterine pregnancy \\ - uterus \\ Schlüsselwörter \\ - assistierte Reproduktion \\ - Extrauteringravidität \\ - Uterus}

Deutschsprachige

Zusatzinformationen online abrufbar unter: www.thieme-connect.de/ ejournals/toc/gebfra received $\quad 12.11 .2014$

revised $\quad 6.1 .2015$

accepted 8.1.2015

\section{Bibliography}

Dol http://dx.doi.org/ 10.1055/s-0035-1545918

Geburtsh Frauenheilk 2015; 75 : 384-388 @ Georg Thieme Verlag KG Stuttgart - New York . ISSN 0016-5751

\section{Correspondence}

Dr. Robert Armbrust

Charité Berlin

Obstetrics

Augustenburger Platz 1

13353 Berlin

robert.armbrust@charite.de

\section{Abstract \\ $\nabla$}

A heterotopic pregnancy in the vicinity of a previous Caesarean section scar (HSP) occurs frequently after fertility treatment. In spite of the low incidence to date, the increasing numbers of Caesarean sections as well as IVF treatment will probably lead to a higher prevalence in the future. Up to now the literature contains only isolated case reports on therapeutic options. These range from conservative management through selective termination of the HSP by injections of methotrexate or potassium chloride into the amniotic sac to invasive methods such as resectoscopic removal or laparoscopy. In the case presented here we describe the successful excision of the HSP by laparotomy with a subsequent uncomplicated Caesarean section and delivery of a healthy baby at the $37+0$ week of pregnancy.

\section{Introduction}

\section{$\nabla$}

A heterotopic scar pregnancy (HSP) after a prior Caesarean section is a rare event with an incidence of ca. 1/30000 [1]. Most such cases occur after assisted reproduction (ART) with implantation of several embryos in patients with a prior cavity-opening procedure in their case history [2]. In the case of a twin pregnancy, one embryo can be implanted correctly while an additional heterotopic - quasi intramurally positioned - embryo usually attaches in the scar of a previous Caesarean section on the anterior wall of the uterus. Due to the increasing number of Caesarean sections as well as the higher frequency of pregnancies after ART, it is expected that the prevalence of heterotopic pregnancies will also increase [3-5]. There are only isolated case reports on such pregnancies in the literature, each with an individualised procedure; the first one

\section{Zusammenfassung \\ $\nabla$}

Eine heterotope Schwangerschaft im Bereich einer ehemaligen Sectionarbe (HNG) entsteht häufig nach Kinderwunschbehandlung. Trotz bisher niedriger Inzidenz ist aufgrund steigender Raten abdomineller Schnittentbindungen sowie IVF-Behandlungen mit einer erhöhten Prävalenz zu rechnen. Bisher existieren in der Literatur nur einzelne Fallberichte über Therapiemöglichkeiten. Diese reichen von konservativem Management über selektive Terminierung der HNG durch Injektion von Methotrexat oder Kaliumchlorid in die Fruchthöhle bis zu invasiveren Methoden wie resektoskopischer Entfernung oder der Laparoskopie. Bei dem hier dargestellten Fall wird eine erfolgreiche Exzision der HNG per Laparotomie dargestellt mit anschließend unkomplizierter Sectio caesarea und Geburt eines gesunden Neugeborenen bei $37+0$ Schwangerschaftswochen.

was published by Salomon et al. in 2003 [3]. The present contribution provides a survey of the current state of knowledge on diagnosis and therapy and describes a case with successful operative therapy and term-near birth of the remaining foetus.

\section{Case Report}

$\nabla$

A 36-year-old, gravida 3, para 3 patient presented in the 7th week of pregnancy with a suspected heterotopic gravidity within a twin pregnancy. The pregnancy resulted from an ART after transfer of 2 embryos. The patient already had given birth to two children by Caesarean section (in 2006 due to foetal breech presentation and 2008 as a primary re-Caesarean), during the latter operation sterilisation was also performed. Details of the indication for sterilisation will not be fur- 


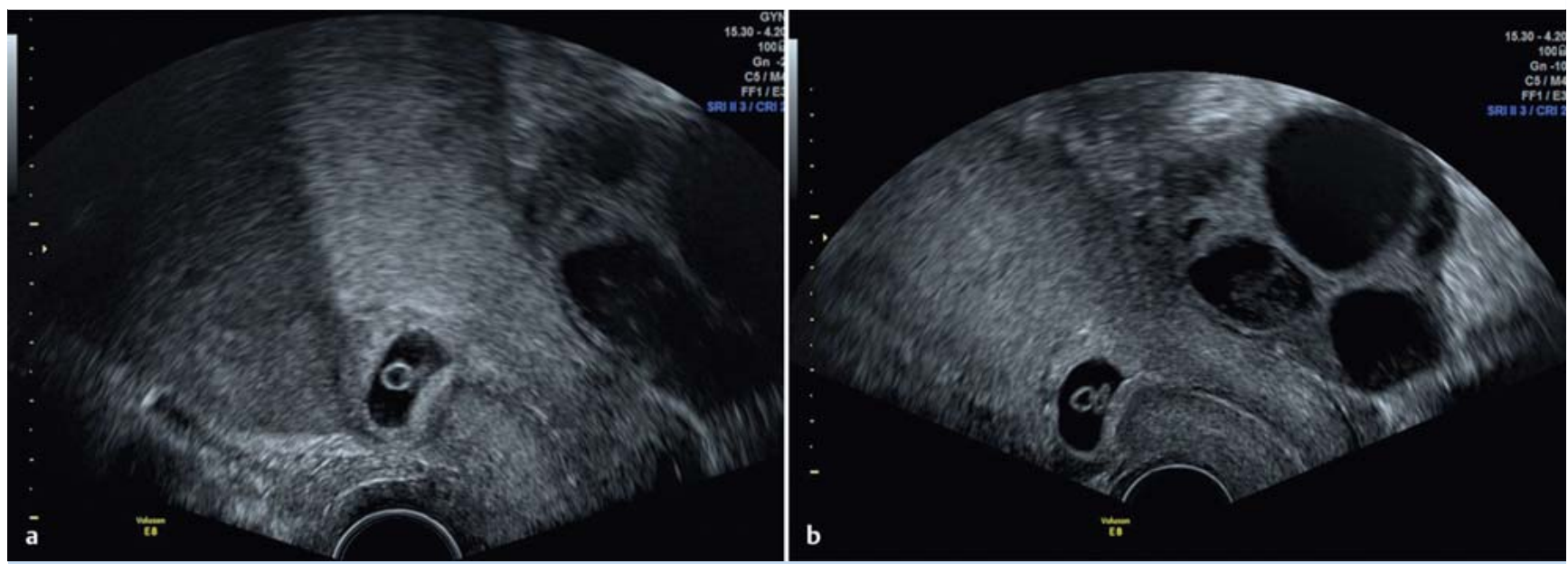

Fig. $\mathbf{1}$ a and $\mathbf{b}$ Heterotopic scar pregnancy on the anterior uterine wall seen on transvaginal ultrasonography (a), myometrium thickness to urinary bladder wall amounts to $2.3 \mathrm{~mm}$. Second intrauterine pregnancy $(\mathbf{b})$.
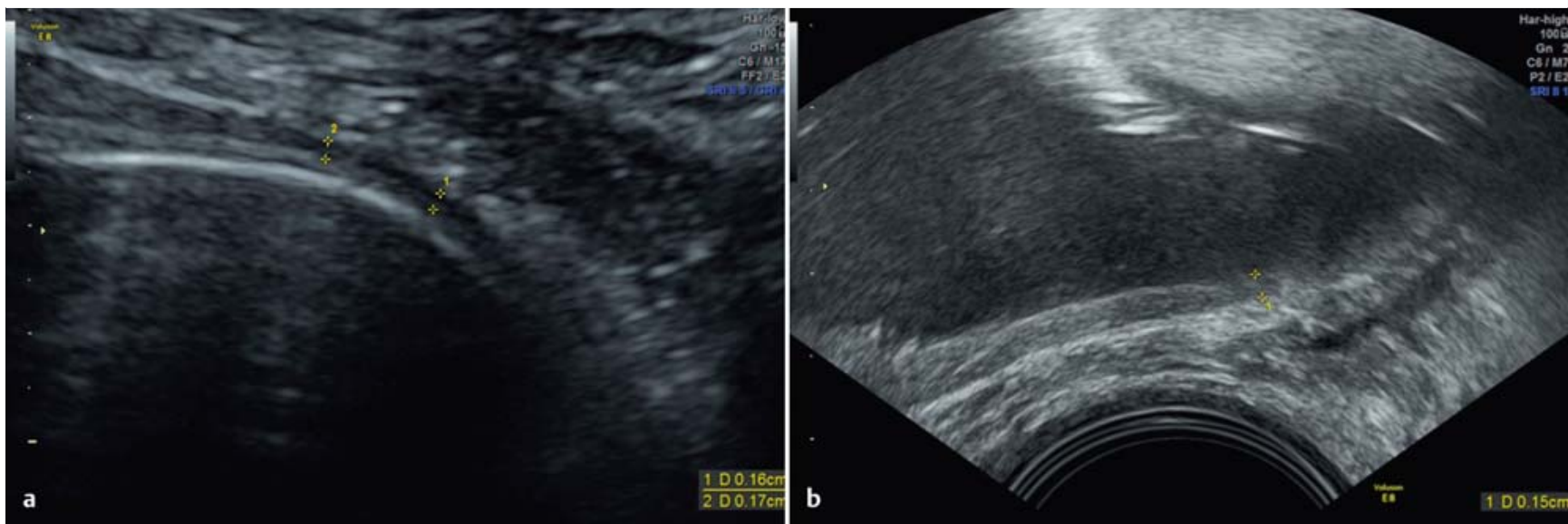

Fig. 2 Lower uterine segment after successful excision of the HSP, transabdominal and transvaginal views in the 31st week of pregnancy.

ther discussed here at the patient's request. The operation, however, is subject to critical appraisal from medical, ethical and psychosocial points of view.

A transvaginal ultrasound examination revealed a correctly implanted and appropriately developed embryo as well as a further amniotic sac with embryonal structures and positive heart activity in the Caesarean section scar on the anterior uterine wall ( $\bullet$ Fig. 1 and 2). The various therapeutic options were discussed with the patient. She explicitly requested a pregnancy-preserving procedure for the second, correctly implanted foetus and decided in favour of the surgical option. By means of a relaparotomy, the scar pregnancy was excised with opening of the uterine cavity ( $\odot$ Fig. 3). After trimming the wound margins, the uterine wall was closed in three layer technique using vicryl sutures. The second amniotic sac was seen to be unaffected in the immediate postoperative period and during the 6-day inpatient residence time. In the further course of the pregnancy screenings paying particular attention to the intact anterior wall of the uterus were unremarkable. The entire course of the pregnancy was without any problems. At the $37+0$ week of pregnancy a primary re-reCaesarean section according to Misgav-Ladach was undertaken with complication-free intra- and postoperative courses (birth weight $2895 \mathrm{~g}$, Apgar 8/9/10, arterial umbilical cord $\mathrm{pH}$ value 7.28 , blood loss ca. $600 \mathrm{~mL}$ ). An inconspicuous lower uterine segment without adhesions was seen intraoperatively.

\section{Review of the Literature}

\section{$\nabla$}

A current literature search (PubMed; cut-off date 18.8.2014) resulted in 24 hits for the key words "heterotopic pregnancy cesarean (Caesarean) scar". 14/24 papers were explicitly concerned with the therapy and outcome of the HSP in twin pregnancies (see 0 Table 1). Of the 14 pregnancies 6 were spontaneous and 8 occurred after in-vitro fertilisation. All published cases were identified by sonography in the first trimester.

Scar pregnancies are classified as extrauterine gravidities and are thus considered to be life-threatening. The main objective of most medical interventions in cases of a heterotopic pregnancy is the removal of the intramurally positioned implantation, if necessary even at the cost of an abortion of the second intrauterine embryo. 


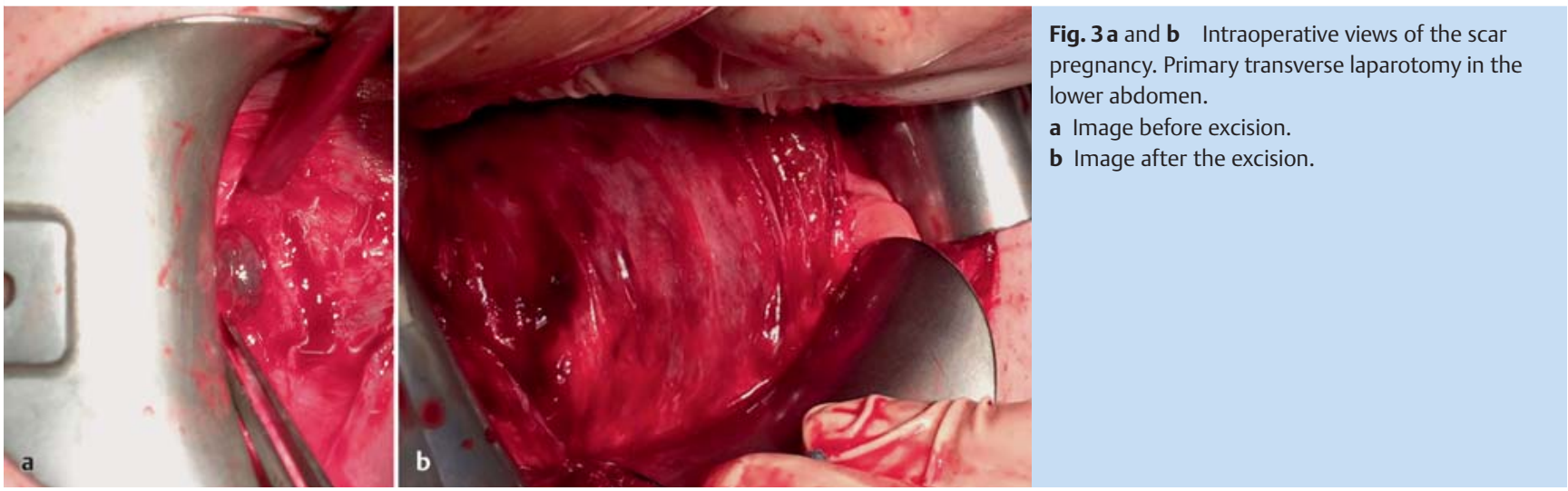

Table 1 Survey of previously published case reports in the English language literature according to our PubMed search. G/P: gravida/para; ART: assisted reproduction IVF or, respectively, ICSI; CS: Caesarean section; PPH: peripartum haemorrhage; f/m: female/male foetus; MTX: methotrexate; KCl: potassium chloride. Only twin pregnancies are included.

\begin{tabular}{|c|c|c|c|c|c|c|c|c|c|}
\hline Author & Case & Age & $\mathbf{G} / \mathbf{P}$ & ED & ART & Method & $\begin{array}{l}\text { Complications } \\
\text { sub partum }\end{array}$ & Outcome & $\begin{array}{l}\text { Previous } \\
\text { CS }\end{array}$ \\
\hline This work & 1 & 36 & $3 / 3$ & 38 & yes & laparotomy + excision & - & $\begin{array}{l}\text { CS 38th week } \\
\mathrm{m} / 2895 \mathrm{~g}\end{array}$ & 2 \\
\hline $\begin{array}{l}\text { Bai et al., } \\
2012\end{array}$ & 2 & 37 & $2 / 1$ & 8 & yes & spontaneous abortion & - & $\begin{array}{l}\text { CS 36th week } \\
\mathrm{m} / 2950 \mathrm{~g}\end{array}$ & 1 \\
\hline $\begin{array}{l}\text { Kim et al., } \\
2014\end{array}$ & 3 & 34 & $5 / 2$ & 6 & no & expectant procedure & $\begin{array}{l}\text { severe } \mathrm{PPH}, \\
\text { placenta accreta }\end{array}$ & $\begin{array}{l}\text { CS 37th week } \\
\mathrm{f} / 2750 \mathrm{~g} \\
\mathrm{f} / 2060 \mathrm{~g}\end{array}$ & 2 \\
\hline $\begin{array}{l}\text { Ugurlucan et al., } \\
2012\end{array}$ & 3 & 34 & $3 / 1$ & 6 & yes & $\begin{array}{l}\text { injection of MTX + } \\
\text { aspiration }\end{array}$ & $\begin{array}{l}\text { placenta praevia totalis } \\
\text { et accreta } \\
\text { severe PPH }\end{array}$ & $\begin{array}{l}\text { CS 38th week } \\
\text { NA }\end{array}$ & 1 \\
\hline $\begin{array}{l}\text { Duenas Garcia et al., } \\
2011\end{array}$ & 4 & 35 & $5 / 3$ & 5 & no & $\begin{array}{l}\text { induced abortion } \\
\text { MTX }\end{array}$ & - & abortion & 3 \\
\hline $\begin{array}{l}\text { Litwicka et al., } \\
2011\end{array}$ & 5 & 31 & $2 / 1$ & 8 & yes & injection of $\mathrm{MTX} / \mathrm{KCl}$ & abruptio placentae & $\begin{array}{l}\text { CS 36th week } \\
\mathrm{m} / 1900 \mathrm{~g} \\
\text { (Miller syndrome) }\end{array}$ & 1 \\
\hline $\begin{array}{l}\text { Gupta et al., } \\
2010\end{array}$ & 6 & 37 & $5 / 4$ & 6 & yes & $\begin{array}{l}\text { aspiration or, respec- } \\
\text { tively, curettage }\end{array}$ & - & termination & 4 \\
\hline $\begin{array}{l}\text { Wang et al., } \\
2010\end{array}$ & 7 & 31 & $3 / 1$ & 7 & yes & $\begin{array}{l}\text { resectoscopic } \\
\text { removal }\end{array}$ & - & $\begin{array}{l}\text { CS 39th week } \\
\mathrm{m} / 3250 \mathrm{~g}\end{array}$ & 1 \\
\hline $\begin{array}{l}\text { Taskin et al., } \\
2009\end{array}$ & 8 & 24 & $2 / 1$ & 9 & no & $\mathrm{KCl}$ injection & $\begin{array}{l}\text { severe } \mathrm{PPH}, \\
\text { transfusions needed }\end{array}$ & $\begin{array}{l}\text { CS 34th week } \\
\mathrm{f} / 2310 \mathrm{~g}\end{array}$ & 1 \\
\hline $\begin{array}{l}\text { Demirel et al., } \\
2009\end{array}$ & 9 & 34 & $2 / 1$ & 6 & no & $\begin{array}{l}\text { resection per } \\
\text { laparoscopy }\end{array}$ & - & $\begin{array}{l}\text { CS 39th week } \\
\mathrm{f} / 3410 \mathrm{~g}\end{array}$ & 1 \\
\hline $\begin{array}{l}\text { Wang et al., } \\
2007\end{array}$ & 10 & 38 & $4 / 3$ & 10 & yes & $\mathrm{KCl}$ injection & $\begin{array}{l}\text { severe } \mathrm{PPH} \text {, ligature } \\
\text { of } \mathrm{A} \text {. hypogastrica }\end{array}$ & $\begin{array}{l}\text { CS 35th week } \\
\mathrm{m} / 1820 \mathrm{~g}\end{array}$ & 3 \\
\hline $\begin{array}{l}\text { Yazicioglou et al., } \\
2004\end{array}$ & 11 & 23 & $2 / 1$ & 6 & no & $\mathrm{KCl}$ injection & abruptio placentae & $\begin{array}{l}\text { CS 30th week } \\
\mathrm{m} / 1530 \mathrm{~g}\end{array}$ & 1 \\
\hline $\begin{array}{l}\text { Hsieh et al., } \\
2004\end{array}$ & 12 & 38 & $4 / 2$ & 6 & yes & $\begin{array}{l}\text { resectoscopic } \\
\text { aspiration }\end{array}$ & - & $\begin{array}{l}\text { CS 32th week } \\
\mathrm{f} / 1980 \mathrm{~g}\end{array}$ & 2 \\
\hline $\begin{array}{l}\text { Salomon et al., } \\
2003\end{array}$ & 14 & 36 & $4 / 1$ & 8 & yes & $\mathrm{KCl}$ injection & severe PPH & $\begin{array}{l}\text { CS 36th week } \\
\mathrm{f} / 2800 \mathrm{~g}\end{array}$ & \\
\hline
\end{tabular}

Several therapeutic options with preservation of the correctly implanted embryo can be found in the available case reports:

\section{Expectant procedure}

In an article published in 2013, Kim et al. reported on the as yet only example of a wait-and-see procedure with a primary Caesarean section in the 37th week of pregnancy and the birth of two vital babies: however, a severe postpartum bleeding due to placenta accreta occurred. Kim et al. (2013) point out that an expectant procedure is associated with high risks. In the reported case, furthermore, the implantation occurred on the inside of the scar and the embryo developed inwards in an intrauterine direction [2].

\section{Drug procedure}

There are 10 case reports dealing with injections of potassium chloride $(\mathrm{KCl})$ or methotrexate (MTX) in the HSP; in some cases the embryonal structures were aspirated and in other cases a wait-and-see policy was followed. Litwicka et al. (2011) injected additional MTX. On average, the Caesarean section was per- 
formed in the 35th week of pregnancy (min. 30 - max. 38) and thus earlier than in the cases of operative interventions $[3,4,8-$ 14]. Also in two cases an immediate and severe postpartum bleeding occurred, in one case requiring ligation of the hypogastric artery. In the literature there are also reports of a primary termination of pregnancy with MTX. With this procedure the teratogenic potential of methotrexate for the remaining foetus must be taken into consideration. Furthermore the fact that this is an off-label use of MTX in obstetrics must be mentioned. There are several modalities with differing dosages and time intervals. In the case report described here doses of $50 \mathrm{mg} / \mathrm{m}^{2}$ body surface area were always used. Damage due to the teratogenic potential was not mentioned in any of the papers.

\section{Operative procedure}

Demirel et al. (2009) performed a laparoscopic excision of the scar pregnancy, the intrauterine foetus was delivered by (an uncomplicated) Caesarean section in the 38th week of pregnancy [6]. The second case report of an operative intervention was published by Wang et al. in 2010 [7]: a resectoscopic ablation was carried out with subsequent curettage in this region [10]. Here also the Caesarean section was performed near term and was free of complications. The resectoscopic procedure should only be employed when the amniotic sac is unambiguously developing in an intrauterine manner and is done at the cost of an increased risk of rupture. The case report presented here is thus the third published operative intervention, but the first to use a primary laparotomy. Severe bleeding complications did not occur in our own case presented here or after laparoscopic excisions.

\section{Discussion \\ $\nabla$}

The management of a heterotopic pregnancy in the vicinity of the scar from a previous Caesarean section is a particular challenge, especially in women with a strong desire to have children. Due to the increasing rates of delivery by Caesarean section and of assisted reproduction, an increasing incidence of this up to now rare entity is to be expected. An ectopic pregnancy can lead to severe bleeding and the risk of uterine rupture is higher. Vial et al. (2000) assume two different scenarios for its occurrence: as the less risky form the authors postulate the implantation of the embryo rather on the inside of the scar with continuing growth in the direction of the uterine cavity. In such a case, although the risk of rupture is lower, the risk of bleeding is considered to be high. In the second scenario a deep implantation in the region of the previously formed scar occurs with a high risk for uterine rupture. There are hints in the literature that an HSP can lead to a placenta accreta or percreta $[15,16]$, for example, after a presumed successful injection of methotrexate and selective embryo reduction. Sonographic diagnostic methods are generally hindered by the unfavourable localisation mostly in the region of the anterior wall and the presence of only a small amniotic sac as well as the absence of clinical symptoms [17]. A high-resolution transvaginal sonographic examination will usually be successful. Colour-coded Doppler sonography is able to visualise trophoblast vessels and thus support the diagnosis. When fertility treatment or, respectively, the transfer of one or more embryos is undertaken in a patient with a prior cavity opening uterus operation in her case history, one should also take an HSP into consideration. When the diagnosis is made early, i.e., in the first trimester, it is possible to choose between terminating both pregnancies and the above-mentioned therapeutic options (operative excision of the HSP with subsequent wound closure of the uterine defect, drug-induced selective termination of the HSP by injection of $\mathrm{KCl}$ or MTX and an expectant wait-and-see procedure). According to the latest literature, the latter appears to carry the highest risk for haemorrhage. On injection of $\mathrm{KCl}$ or, respectively, MTX with subsequent aspiration, the complete absorption of trophoblastic tissue is not always certain so that in the further course of the pregnancy an impaired placentation with a consecutively increased risk of bleeding may occur. The operative intervention represents the safest therapeutic option, especially for women who have not yet completed their family planning. On the one hand, the risk of placenta accreta or percreta is quasi excluded whereas, on the other hand, the lower segment of the uterus can be stabilised by surgical correction and multi-layer suturing, thus leading to a lower risk of uterine rupture. In summary, it can be stated that, in cases of heterotopic scar pregnancies, the afflicted pregnant patient should also be informed of the possibilities for a pregnancy-preserving procedure for the intrauterine implanted foetus. At the same time she must be comprehensively informed of the risks. Furthermore, the consecutive risk of a scar pregnancy should be critically considered as part of the indication for a Caesarean section. With regard to the choice of an operative intervention, no generally valid recommendations can be given at present due to the lack of sufficient literature reports; however, the open abdominal procedure can be performed with success.

\section{Conflict of Interest}

None.

\section{References}

1 Alptekin H, Dal Y. Heterotopic pregnancy following IVF-ET: successful treatment with salpingostomy under spinal anesthesia and continuation of intrauterine twin pregnancy. Arch Gynecol Obstet 2014; 289: 911-914

2 Kim M, Jun HS, Kim JY et al. Successful full-term twin deliveries in heterotopic cesarean scar pregnancy in a spontaneous cycle with expectant management. J Obstet Gynaecol Res 2014; 40: 1415-1419

3 Salomon LJ, Fernandez H, Chauveaud A et al. Successful management of a heterotopic cesarean scar pregnancy: potassium chloride injection with preservation of the intrauterine gestation: case report. Hum Reprod 2003; 18: 189-191

4 Timor-Tritsch IE, Monteagudo A. Unforeseen consequences of the increasing rate of cesarean deliveries: early placenta accreta and cesarean scar pregnancy. A review. Am J Obstet Gynecol 2012; 207: 14-29

5 Barnhart KT. Early pregnancy failure: beware of the pitfalls of modern management. Fertil Steril 2012; 98: 1061-1065

6 Demirel LC, Bodur H, Selam B et al. Laparoscopic management of heterotopic cesarean scar pregnancy with preservation of intrauterine gestation and delivery at term: case report. Fertil Steril 2009; 91: 5-7

7 Wang CJ, Tsai F, Chen C et al. Hysteroscopic management of heterotopic cesarean scar pregnancy. Fertil Steril 2010; 94: 5-8

8 Yazicioglu HF, Turgut S, Madazli R et al. An unusual case of heterotopic twin pregnancy managed successfully with selective feticide. Ultrasound Obstet Gynecol 2004; 23: 626-627

9 Hsieh BC, Hwang JL, Pan HS et al. Heterotopic caesarean scar pregnancy combined with intrauterine pregnancy successfully treated with embryo aspiration for selective embryo reduction: case report. Hum Reprod 2004; 19: 285-287

10 Wang CN, Chen CK, Wang HS et al. Successful management of heterotopic cesarean scar pregnancy combined with intrauterine pregnancy after in vitro fertilization-embryo transfer. Fertil Steril 2007; 88: 706. e13-706.e16

11 Taskin S, Taskin EA, Ciftci TT. Heterotopic cesarean scar pregnancy: how should it be managed? Obstet Gynecol Surv 2009; 64: 690-695 
12 Ugurlucan FG, Bastu E, Dogan M et al. Management of cesarean heterotopic pregnancy with transvaginal ultrasound-guided potassium chloride injection and gestational sac aspiration, and review of the literature. J Minim Invasive Gynecol 2012; 19: 671-673

13 Litwicka K, Greco E. Caesarean scar pregnancy: a review of management options. Curr Opin Obstet Gynecol 2011; 23: 415-421

14 Dueñas-Garcia OF, Young C. Heterotopic cesarean scar pregnancy associated with a levonorgestrel-releasing intrauterine device. Int J Gynaecol Obstet 2011; 114: 153-154
15 Gupta R, Vaikousi E, Whitlow B. Heterotopic caesarean section scar pregnancy. J Obstet Gynaecol 2010; 30: 626-627

16 Sinha P, Mishra M. Caesarean scar pregnancy: a precursor of placenta percreta/accreta. J Obstet Gynaecol 2012; 32: 621-623

17 OuYang Z, Yin $\mathrm{Q}, \mathrm{Xu}$ Y et al. Heterotopic cesarean scar pregnancy: diagnosis, treatment, and prognosis. J Ultrasound Med 2014; 33: 15331537 